University of Wollongong

Research Online

Faculty of Law, Humanities and the Arts Papers (Archive)

Faculty of Arts, Social Sciences \& Humanities

$1-1-2013$

Academic employment and gender equity legislation in Australia and Japan, 1970-2010

Kirsti Rawstron

University of Wollongong, k.rawstron@gmail.com

Follow this and additional works at: https://ro.uow.edu.au/lhapapers

Part of the Arts and Humanities Commons, and the Law Commons

Research Online is the open access institutional repository for the University of Wollongong. For further information contact the UOW Library: research-pubs@uow.edu.au 


\title{
Academic employment and gender equity legislation in Australia and Japan, $1970-2010$
}

\author{
Abstract \\ Purpose - The purpose of this paper is to examine the rate of change of men and women's employment as \\ university academic staff in Australia and Japan; and, drawing on quantitative methods, show differences \\ in the rate of change since the introduction of anti-sex discrimination legislation. The author also includes \\ a discussion of programmes designed to increase female participation in academic positions to provide \\ background to the existing changes. \\ Design/methodology/approach - Using statistics published by the Ministries of Education of both \\ countries, a time series of female participation at each level of academic staff was constructed. \\ Breakpoint analysis is used to model the changes in the rate of change before and after the legislation \\ was introduced. \\ Findings - Both Australia and Japan have seen an increase in female participation rates in academic \\ employment at all levels since the introduction of anti-sex discrimination legislation. In addition, the rate \\ of increase of female participation has increased at almost every level of academic staff in both countries \\ between 1970 and 2010. \\ Originality value - Through setting out the changes in female participation at individual levels of academic \\ staff in Japan and Australia, this study sets the stage for future qualitative work exploring why differences \\ in the numbers of female and male staff continue. A further use is the provision of a clear data set for use \\ in teaching and policy construction through showing the increases in female participation in academia \\ between 1970 and 2010.
}

\section{Keywords}

2010, academic, employment, gender, equity, legislation, australia, 1970, japan

Disciplines

Arts and Humanities | Law

\section{Publication Details}

Rawstron, K. 2013, 'Academic employment and gender equity legislation in Australia and Japan, 1970-2010', Equality, Diversity and Inclusion, vol. 32, no. 8, pp. 777-793. 


\section{Academic Employment and Gender Equity Legislation in Australia and Japan, 1970 - 2010}

Purpose - This article examines the rate of change of men and women's employment as university academic staff in Australia and Japan; and, drawing on quantitative methods, shows differences in the rate of change since the introduction of anti-sex discrimination legislation. I also include a discussion of programs designed to increase female participation in academic positions to provide background to the existing changes.

Design/methodology/approach - Using statistics published by the Ministries of Education of both countries, a time series of female participation at each level of academic staff was constructed.

Breakpoint analysis is used to model the changes in the rate of change before and after the legislation was introduced.

Findings - Both Australia and Japan have seen an increase in female participation rates in academic employment at all levels since the introduction of anti-sex discrimination legislation. In addition, the rate of increase of female participation has increased at almost every level of academic staff in both countries between 1970 and 2010.

Originality/Value - Through setting out the changes in female participation at individual levels of academic staff in Japan and Australia, this study sets the stage for future qualitative work exploring why differences in the numbers of female and male staff continue. A further use is the provision of a clear data set for use in teaching and policy construction through showing the increases in female participation in academia between 1970 and 2010.

Keywords: gender equity; legislation; academic employment; Australia; Japan

Article classification: Research paper

\section{Introduction}

Gender imbalances remain amongst university academic staff in many countries, despite widespread legislative efforts and affirmative action programs aimed at addressing inequalities and discrimination in employment. Two examples of this are continuing gender disparities in university employment in Australia and Japan, where women remain clustered in the lower levels of academic staff. Australia and Japan have been selected for comparison as the university sectors in both countries have expanded as part of the massification of the global higher education system during the late twentieth century, and both countries introduced anti-sex discrimination legislation with regards to inequalities in employment during the mid-1980s. The patterns of female participation in academia, however, differ between the two countries, with women accounting for a larger proportion of staff in Australia. In this article, in order to contextualise the long-term trends in employment 
inequalities in universities in these countries, I describe some of the affirmative action policies focused on improving gender equity in universities.

Universities, as other large organisations, continue to have gendered assumptions embedded in their structures and practices and thus reproduce gender inequalities (Acker, 2012). One of the questions concerning equal opportunity policies is whether and how they can contribute to changing these (often unspoken) assumptions. Both Australia and Japan introduced equal employment opportunity laws in the 1980s. The two laws examined here are the Australian Sex Discrimination Act (enacted March and effective August 1984, hereafter SDA) and the Japanese Danjo Koyō Kikai Kintō-hō (Equal Employment Opportunity Law, enacted May 1985, effective April 1986, hereafter EEOL). I hypothesise that the continuing lack of equality in staff numbers following the introduction of these laws, as well as the continued dominance of men in senior academic positions supports the idea that the abstract 'ideal' academic worker remains coded as male. This abstract ideal has become more fluid in recent years (Bleijenbergh et. al., 2013), and is disguised within a discourse which portrays universities, like other organisations, as gender-neutral and meritocratic in their staffing preferences (Acker, 1990).

Although there is a continuing lack of gender equality in the higher levels of academic staff in Japan and Australia, changes in the gender balance of staff in academia are occurring. In this article, I explore changes in women's over- and under-representation at different levels of academic staff between 1970 and 2010 before and after the introduction of anti-sex discrimination legislation. Four levels of staff from each country are examined in this article, using data drawn from the Japanese Monbu Tōkei Yōran (Education Statistics Yearbook) and the Australian Selected Higher Education: Staff publications. As shown below, the expansion of higher education in Australia and Japan has been accompanied by an increase in the proportion of female academic staff at all levels. This article can serve as a preliminary 
empirical study showing changes in the proportion of male and female staff over a forty year period, and will support future qualitative research into why these changes occurred - and what changes are still to come.

\section{Literature Review}

The expansion of the tertiary education sector in Japan and Australia is a local reflection of the global trend of converting higher education from an elite to a mass system (Frank \& Meyer, 2007). This transition has been driven by the conception of higher education as having a key role in knowledge-based socioeconomic growth (Skilbeck \& Esnault, 1993; Frank \& Meyer, 2007). The greater number of students has led to demands for greater numbers of teaching staff. The expansion of higher education to attract a diverse student population has drawn attention to existing inequalities and a lack of diversity within academic staff.

In Japan, the number of four-year universities increased from 382 to 778 institutions between 1970 and 2010, while the number of students more than doubled from 1.4 million students to 2.9 million students and the total number of academic staff increased from 75,929 to 172,776 (Sōmushō Tōkeikyoku Tōkei Kenshūjo, 1971; 2011). The Australian tertiary education system is smaller, but has seen a more significant expansion: from fifteen universities to 38 , accompanied by a $900 \%$ increase in the number of students (from 116,778 to 1.1 million) and a $600 \%$ increase in the total number of academic staff (from 7368 to 46,969) between 1970 and 2010 (Australian Bureau of Statistics, 1971; Department of Education, Employment and Workplace Relations, 2011).

Within this expansion, however, social constructions of gender and other dimensions of difference have shaped the patterns of participation in higher education due to "persistent 
and deeply institutionalized ideologies" (Bradley \& Charles, 2003, p. 248). While it is increasingly socially acceptable for women to seek undergraduate tertiary education (with women accounting for $57 \%$ of Australian and $42 \%$ of Japanese undergraduate students at four-year universities), the proportion of women gaining postgraduate qualifications remains low (Department of Education, Employment and Workplace Relations, 2011; Sōmushō Tōkeikyoku Tōkei Kenshūjo, 2011). Furthermore, in both countries, women are rare in the most senior academic positions, and inequalities between male and female employment in general remain.

Both Japan and Australia are party to the United Nations Covention on the Elimination of All Forms of Discrimination Against Women, and both countries have laws concerning equal employment opportunity. While political support for employment equality in developed countries is almost universal (Wirth, 2001), in practice men and women experience unequal employment opportunities in many developed countries - including Australia and Japan. Equal opportunity as a concept is derived from a "liberal political philosophy which asserts the rights of the individual to universally applicable standards of justice and citizenship" (Webb, 1997, p. 159), and is enshrined within both the Australian Sex Discrimination Act and the Japanese Equal Employment Opportunity Law. Equality of opportunity does not always lead to equality of result, however, especially since such legislation often addresses only equality in the workforce - rather than equality in both paid and unpaid labour. While discrimination on the basis of sex by employers is illegal in both of these countries, there is a large difference between legal victories and broad social change (Gaze, 2010). Without changes in the division of household labour and other non-work responsibilities, women are unable to take full advantage of equal employment opportunities. The effects of the different social situations of men and women can be seen in the lack of women in senior academic positions in Japan and Australia. Although there are no legislative 
barriers to women seeking high level positions in academia, social values both inside and outside the university limit women's employment options.

While gender is often presented as an "immutable category of difference", in reality gender is produced, endorsed and modified through on going social and cultural processes and interactions, rather than by individuals in isolation (Butler, 1997, p. 14; Panteli et al., 2001; Scott, 1988). Gender is socially and culturally constructed as a divider used to classify and partition the population based on stereotypical imaginings of what 'women' or 'men' are 'best suited' or 'able' to do, despite scientific evidence that men and women "unambiguously represent exemplars of the same underlying attributes rather than qualitatively distinct categories of human characteristics" (Carothers \& Reis, 2012, p. 404).

Despite the lack of measurable differences between men and women on a range of abilities (Carothers \& Reis, 2012), beliefs surrounding gender difference are so deeply embedded within society that "individuals' occupational aspirations tend to become limited to alternatives regarded as appropriate for their gender" (Cejka and Eagly, 1999, p. 415). These beliefs pay little attention to the needs or abilities of individuals, and are instead presented as "fundamental differences" between all women and all men (Scott, 1988, p. 168; see also Anker, 1998). Gender is thus used as a category to restrict and control sectors of the population (Thornton, 1990). Social penalties for violating societal norms or stereotypes of gendered behaviour can be severe (Heilman and Wallen, 2010; Okimoto and Brescoll, 2010; Tyler and McCullough 2009), so that sociocultural norms of gender can be highly resistant to change.

While formal, legal restrictions on women's access to employment and education have largely been removed in Japan and Australia, sociocultural norms continue to impact on women's educational and career choices through assigning the majority of the burden of non- 
work responsibilities to women rather than men. These wider social norms combine with particular aspects of academic culture (in which academics "are partly defined by historical assumptions about a particular role and institutional identity, within a national cultural tradition and social structure" [Kim, 2005, p. 91]) to create an environment where women often feel excluded (Probert, 2005).

The scarcity of women in senior academic positions can be partially attributed to the underlying masculine culture of universities, wherein entrenched values and cultural expectations are not easily dislodged nor easily reconciled with the lived experiences of nontraditional academics (Luke, 2001; Verbos \& Humphries, 2012), as well as to differences in human capital (Probert, 2005). Bain and Cummings (2000) identified two variables which impede the advancement of women into higher ranks of academia: experience and academic productivity (research output), thus supporting the human capital argument which states that those who have higher qualifications and more workplace experience should receive higher wages and higher status occupations (Anker, 1997). As women tended to have less workplace experience, or a more interrupted workplace experience than men, their human capital has historically been lower.

There is limited evidence to support the human capital theory approach to gender inequality: women have historically been concentrated at the lower levels of academia partially because they had lower levels of education and less work experience than their male peers, and did not "seem to attack the career structure as vigorously as men" (Probert, 2005, p. 58). There is greater evidence, however, to suggest that female participation in the academic workforce is constrained by differences in how men and women reconcile work and family responsibilities, rather than by differences in their human capital (Probert, 2005; Wirth, 2001). Bailyn (2003) identifies the psychological pressure to prioritise work over outside interests as a strong barrier to participation in senior academic positions, particularly for those with 
family responsibilites. In Japan, the difficulties in combining research work with family responsibilities have been identified as a leading reason for the under-representation of women in academic positions (Kameda, 2011), and similar patterns have been identified in other countries (Wirth, 2001). In Australia, Probert states that "all things being equal", women will achieve the same level as men - the issue is making all things equal in the first place (Probert, 2005; see also Winchester et. al. 2005).

The social construction of gender in both Australia and Japan is predicated on the female-homemaker/male-breadwinner model (Baird, 2011; Mackie, 2003). There are, however, differences. In Australia, the possibility of undertaking fractional employment for some periods of time makes it easier for some people to reconcile home life and work life. It has also been argued that universities have a patriarchal culture, where sociocultural norms hinder female advancement into the higher levels of academia. Both legislation and workplace policies seek to change or work around this block, but until both men and women participate equally in family and work responsibilities, women's career options will remain limited. My data supports existing research stating that differences between male and female career paths have less to do with the labour market and more to do with social practices concerning responsibilities for childcare and domestic work (Probert et. al, 1998).

In studies of gender equity, it is often female participation which is problematized. For example, statistics relating to employment will often report "total" and "female" numbers, highlighting the female worker as unusual (see, for example, Monbushō, 2011). While I argue that the gender disparity issue is more often due to male over-representation than female under-representation, I have examined female participation in this article so as to provide easier comparison with existing research in this area.

\section{University Employment}

Japan 
In the Japanese case, the categories examined are Professors (kyoju), Associate Professors (jo-kyōju or jun-kyōju), Lecturers (kōshi) and Assistants (joshu) (Poole, 2010). ${ }^{[1]}$ As shown in Figure 1, the number of people working at each of these four levels has increased considerably between 1970 and 2010. This reflects the expansion of the Japanese higher education system, as discussed above.

Figure 1 Total Academic Staff at Four Levels by Gender (Japan, 1970 and 2010) ${ }^{[2]}$

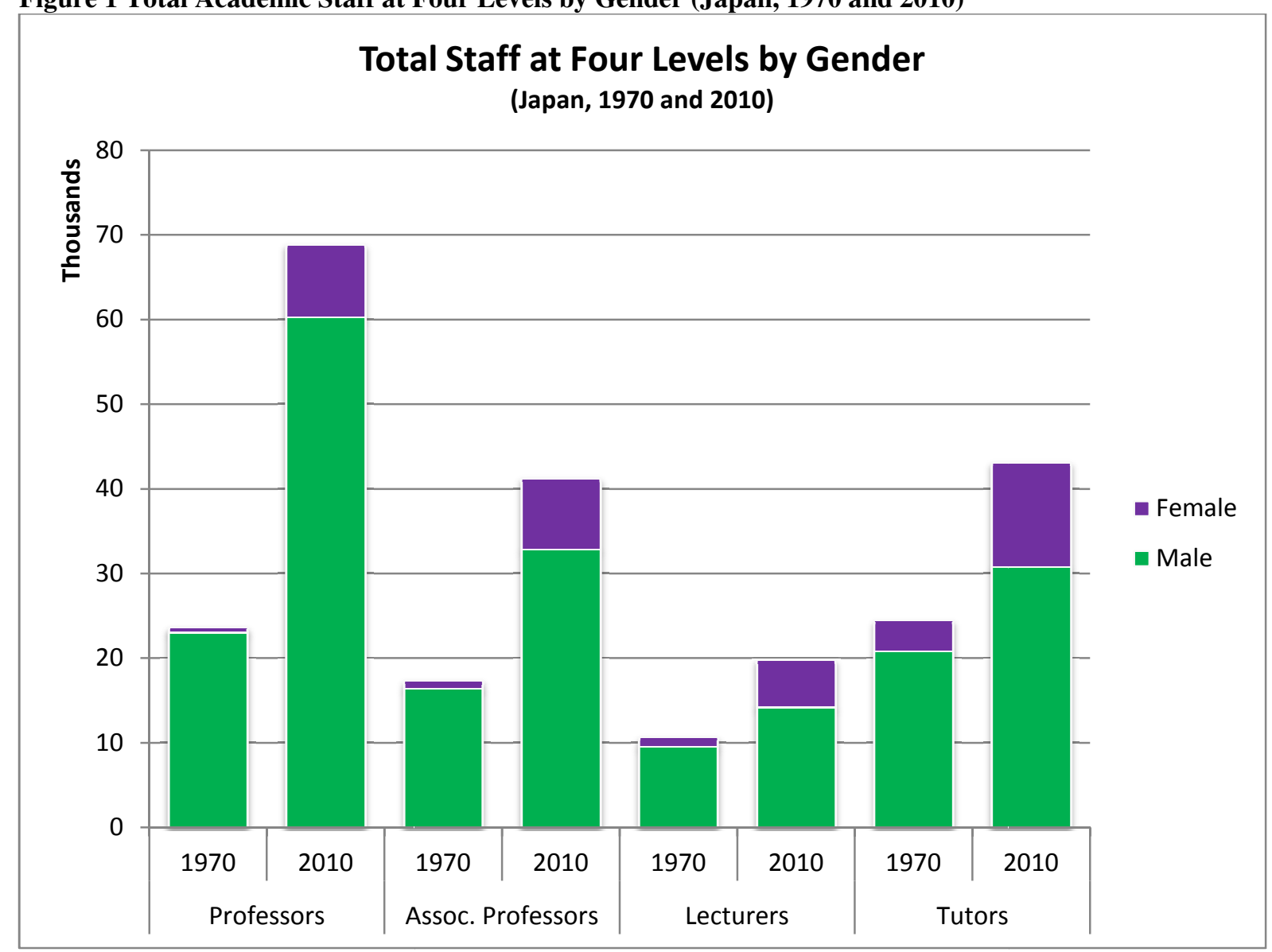

Alongside these increases in total staff numbers, there has also been a marked increase in the proportion of women at each of these staff levels (Table 1). In 1970, there were 23,571 Professors in Japan (2.64\% of who were female). By 1986, the year the Equal Employment Opportunity Law was implemented, there were 38,510 Professors $(4.44 \%$ female), and in 2010 this number rose to 68,787 Professors (12.47\% female). In 2010 there were also 41,189 Associate Professors (20.37\%), 19,738 Lecturers (28.33\%) and 43,062 Assistants (28.71\%). 
Table 1 Number, Level and Per cent Female of Japanese University Staff (1970, 1986 and 2010) ${ }^{[3]}$

\begin{tabular}{|l|l|l|l|l|l|l|}
\hline & $\mathbf{1 9 7 0}$ & $\mathbf{1 9 8 6}$ & $\mathbf{2 0 1 0}$ & \\
\hline & Total Staff & \% Female & Total Staff & \% Female & Total Staff & \% Female \\
\hline Professors & 23571 & $2.64 \%$ & 38510 & $4.44 \%$ & 68787 & $12.47 \%$ \\
\hline $\begin{array}{l}\text { Associate } \\
\text { Professors }\end{array}$ & 17312 & $5.72 \%$ & 26506 & $7.23 \%$ & 41189 & $20.37 \%$ \\
\hline Lecturers & 10642 & $10.93 \%$ & 14876 & $10.31 \%$ & 19738 & $28.33 \%$ \\
\hline Assistants & 24404 & $14.97 \%$ & 33407 & $13.65 \%$ & 43062 & $28.71 \%$ \\
\hline Total & 75929 & $8.47 \%$ & 113299 & $8.58 \%$ & 172776 & $20.21 \%$ \\
\hline
\end{tabular}

\section{Australia}

In the Australian case, the examined staff levels are Above Senior Lecturers (Levels

D and E, as ranked by the Department of Industry, Innovation, Science, Research and Tertiary Education), Senior Lecturers (Level C), Lecturers (Level B) and Below Lecturers (Level A). The Australian tertiary education labour market is smaller than the Japanese, and has a more gender balanced workforce: in 2010, there were 11,836 Above Senior Lecturers (26.7\% female), 10,868 Senior Lecturers (41.3\% female), 15,682 Lecturers (51.5\% female) and 8583 Below Lecturers $\left(55.2 \%\right.$ female). ${ }^{[4]}$ Table 2 shows the number of staff at all four of these levels in 1970, 1984 (the year that the Sex Discrimination Act (SDA) was implemented) and 2010.

Table 2 Number, Level and Per cent Female of Australian University Staff (1970, 1984 and 2010) ${ }^{[5]}$

\begin{tabular}{|l|l|l|l|l|l|l|}
\hline & $\mathbf{1 9 7 0}$ & $\mathbf{1 9 8 4}$ & $\mathbf{2 0 1 0}$ & \\
\hline & Total Staff & \% Female & Total Staff & \% Female & Total Staff & \% Female \\
\hline $\begin{array}{l}\text { Above } \\
\text { Senior }\end{array}$ & 1513 & $2.45 \%$ & 2521 & $4.01 \%$ & 11836 & $26.67 \%$ \\
\hline Senior & 2014 & $5.86 \%$ & 3720 & $9.70 \%$ & 10868 & $41.33 \%$ \\
\hline Lecturers & 2117 & $12.66 \%$ & 2431 & $22.71 \%$ & 15682 & $51.51 \%$ \\
\hline Below & 1782 & $33.58 \%$ & 1782 & $43.60 \%$ & 8583 & $55.20 \%$ \\
\hline Total & 7368 & $13.60 \%$ & 10454 & $17.13 \%$ & 46969 & $43.57 \%$ \\
\hline
\end{tabular}

Between 1970 and 2010, there has been a marked increase in the number of staff at all of these levels, which has been accompanied by increasing gender equity among the staff at each level (Figure 2). 
Figure 2 Total Academic Staff at Four Levels by Gender (Australia, 1970 and 2010) ${ }^{[6]}$

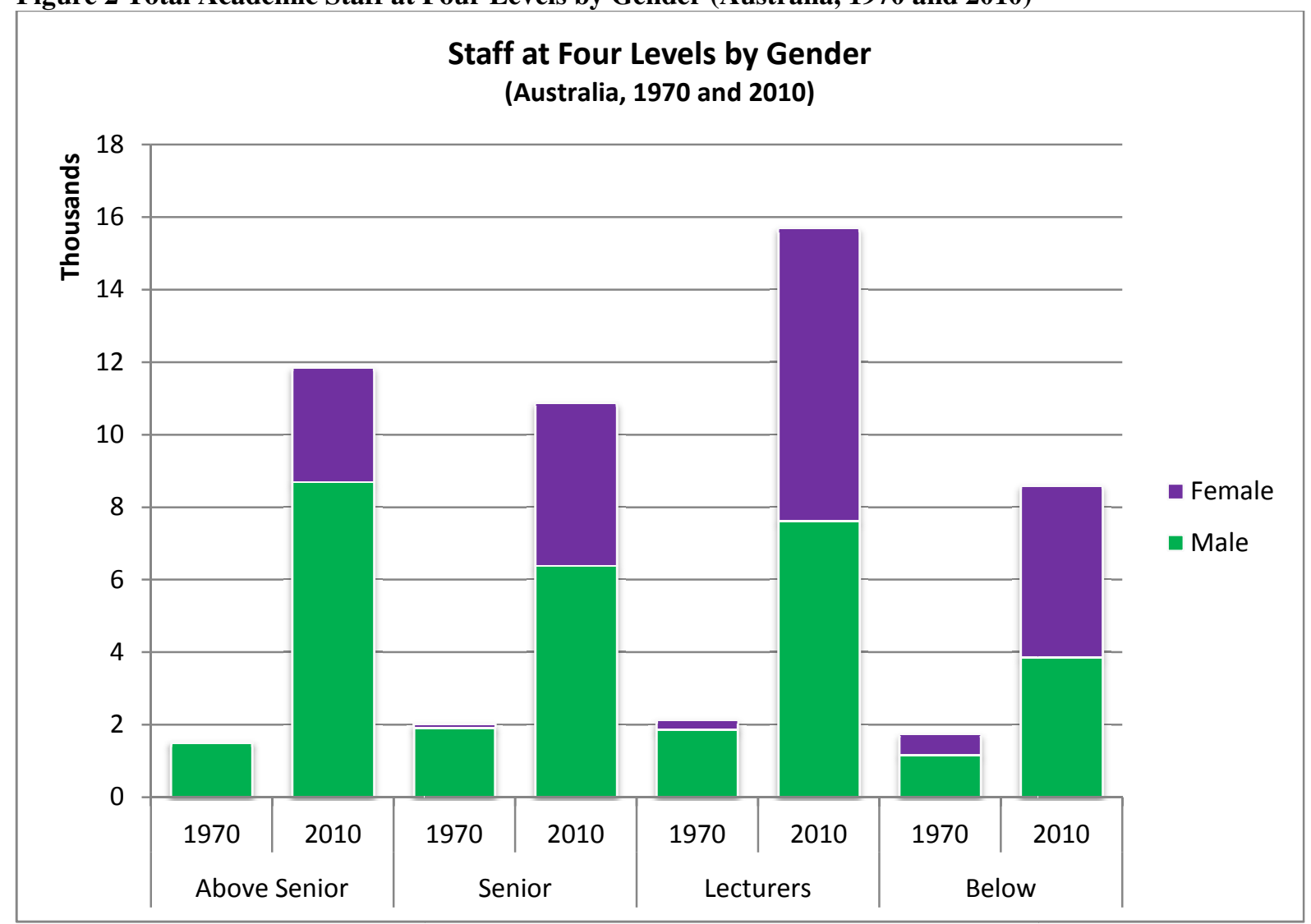

Though there are differences between the two countries, there are clear changes in the proportions of men and women amongst academic staff before and after the introduction of anti-sex discrimination legislation, as will be explained further.

\section{Legislation}

Two examples of legislative remedies for workplace discrimination are antidiscrimination/equal opportunity (AD/EO) legislation and affirmative action (AA) legislation. The effects of both, however, are constrained by the fact that they operate within specific, inherited legal structures which constrain their effectiveness (Bacchi, 1990). The two legislation types have two distinct goals: $\mathrm{AD} / \mathrm{EO}$ legislation is prohibitive in nature, and leads to individual solutions to specific occurences of discrimination. It provides a baseline of what is considered to be overt discrimination, but does not necessarily alter widespread patterns of disadvantage. This is where AA legislation and policies come into effect. Such policies recognise that it is not sufficient to outlaw specific overt forms of discrimination. 
Rather, there are systematic, historic disadvantages that cannot be overcome on a case-bycase basis (Strachan et al., 2007). The laws examined in this study are AD/EO laws, which were followed by AA programs specifically aiming to encourage the inclusion of women at all levels of university staff. Examples of these plans include the Universities Australia Strategy for Women: 2011-2014 and the Japanese Program Supporting Positive Action for Female Researchers (from 2009 to 2014), discussed below.

The Japanese Equal Employment Opportunity Law aimed at "ensuring equal opportunities and treatment of men and women" (Oda, 1992, p. 325) and outlawed direct discrimination in terms of retraining, welfare, retrenchment, recruitment, hiring, transfers and promotions. The EEOL required employers to endeavour to give both sexes equal opportunities in terms of recruitment and hiring, job assignment and promotions, and it specified that women could not be discriminated against in terms of education and training, benefits, retirement or dismissal. Many of these provisions had already been gained through litigation, with reference to the 1947 Rōdō Kijun Hō (Labour Standards Law) and Article 14 of the Constitution. The Equal Employment Opportunity Law addressed these issues in a more specific and detailed way. ${ }^{[7]}$

The EEOL was introduced as part of the process of Japan's ratification of the United Nations' Convention on the Elimination of All Forms of Discrimination Against Women (CEDAW) and sought to reconcile international and domestic norms of gendered behaviour. While the EEOL aimed to prohibit discrimination against female employees, it failed to define sexual discrimination. In its initial form, this law did not address the social constructions of gender which limit the employment opportunities of women (Flowers, 2009). 
While the Japanese Equal Employment Opportunity Law addressed only employment discrimination, the Australian Sex Discrimination Act covered discrimination within employment, education, the provision of goods and services, accommodation, charities and religious bodies. The goal of the SDA was to eliminate "so far as is possible" discrimination on the grounds of sex, marital status or pregnancy (Lake, 1999, p. 264; Strachan et al., 2007, p. 528). The Sex Discrimination Act was introduced as part of an increased emphasis on combatting sex discrimination in Australia in the 1970s and early 1980s and brought Australia into line with its responsibilities under CEDAW. Between 1975 and 1977 South Australia, Victoria and New South Wales all passed anti-discrimination acts which addressed sex discrimination in the workplace, and a Federal Private Senator's Bill was introduced to Parliament in 1981 (although it was adjourned without a vote). Some sections of the Private Senator's Bill were implemented as part of the SDA; others as the subject of the 1986 Affirmative Action (Equal Employment for Women) Act (Sawer, 2004; Thornton and Luker, 2010).

\section{Method}

The introduction of new employment laws marks the end of one era, and the beginning of another. Breakpoint analysis is a method by which one can examine the difference of trends before and after a particular point in time. This point in time is identified as the breakpoint. Linear regression is used to model a trend before and after the breakpoint to present the difference in the slope (or rate of increase) in female participation in the years before and after the introduction of the new laws. This breakpoint is 1984 for the Australian case and 1986 for the Japanese, as these are the years that the new laws were introduced.

I use the following linear regression model to estimate the level and trend in female participation levels for each staff level before the implementation of anti-sex discrimination legislation, and the changes in level and trend following the implementation: 


$$
Y_{t}=\beta_{0}+\beta_{1} * \text { time }+\beta_{2} * \text { implementation }+\beta_{3} * \text { time after implementation }+\varepsilon_{t}
$$

Here, $Y_{t}$ is the female staff participation rate at a specific academic level (Lecturer, Professor, etc.) in year $\mathrm{t}$; time is a continuous variable which indicates time in years from the start of the observation period; implementation is an indicator for time $t$ occurring before or after the implementation of the law; and time after implementation is a continuous variable indicating time in years from the implementation of the new legislation.

For this model, $\beta_{0}$ estimates the participation rate of female staff at a particular academic level in 1970. $\beta_{1}$ estimates the change in trend of female participation in the years before the implementation of the new legislation, and the immediate change in female participation after the implementation is estimated by $\beta_{2}$. The sum of $\beta_{1}$ and $\beta_{3}$ gives us the post-intervention slope, with $\beta_{3}$ alone estimating the change in trend of female participation in the years after the legal change when compared to the trend before the intervention (Perrin, 2009; Wagner et al., 2002).

It is important to note that the results presented here show correlation between the introduction of $\mathrm{AD}$ legislation and increased female participation in academic employment, and not causation. A range of interacting variables cause societal changes such as decreasing gender inequality, and these are not easily modelled. These results, therefore, are indicative of changes in the gender balance following the introduction of new legislation, and can be used to suggest where further changes could be implemented through highlighting areas where little change has so far occurred.

\section{Results}

Breakpoint analysis shows that female participation at all levels of academic staff was higher in Australia and Japan in 2010 than it was in the mid-1980s. In both countries, there is an increased percentage of female staff working in academic employment, and the rate at 
which female participation increases each year has generally improved, as expected. What my research shows is how the rate of change has shifted over time.

\section{Australia}

In the Australian case there has been a clear change in the rate of increase in terms of female participation in the total number of academic positions, as seen in Table 4. Prior to the introduction of the SDA in 1984, the slope of total female participation was 0.239 - the percentage of women in all university positions increased at a statistically significant rate of $0.239 \%$ on average between 1970 and 1983 (Table 3a; $p$-value < 0.05). After 1984, this rate increased to an average of $0.854 \%$ ( $p$-value $<0.05)$. This pattern is replicated for female participation at the Above Senior Lecturer, Senior Lecturer, and Lecturer levels (Tables 3b, $3 \mathrm{c}$ and 3d), with statistically significant increases in the slope of female participation occurring after 1984 ( $p$-values $<0.05)$.

The change in trend for Below Lecturers differs from the other staff levels (Table 3e). The rate of increase of female participation of Below Lecturers has fallen from $0.811 \%$ prior to 1984 to $0.342 \%$ after 1984 ( $p$-value for both trends < 0.05 ). While women are increasing their participation at this staff level, they are doing so at a slower rate after 1984 than before. Moreover, Below Lecturers accounted for a smaller proportion of total academic staff in 2010 than they did in 1970 (18.27\% of total academic staff in 2010, down from $23.40 \%$ in 1970 ). Although it is outside the scope of this paper, I would suggest that the growth in the casualized academic workforce in Australia has caused this change, with more academics being employed as casual/sessional staff rather than in fulltime positions. 
Table 3 Results of Breakpoint Analysis of Female Participation in Academic Staff; Australia

\begin{tabular}{|c|c|c|c|c|c|}
\hline Staff Level & & Coefficient & $\begin{array}{l}\text { Standard } \\
\text { Error }\end{array}$ & $t$-statistic & $p$-value \\
\hline \multirow{4}{*}{$\begin{array}{ll}\text { a. } & \text { Total } \\
\text { Staff }\end{array}$} & Constant & 13.626 & 0.789 & 17.081 & 0.000 \\
\hline & Pre-1984 Trend & 0.239 & 0.094 & 2.549 & 0.015 \\
\hline & $\begin{array}{l}\text { Immediate } \\
\text { Change }\end{array}$ & 4.847 & 0.909 & 5.332 & 0.000 \\
\hline & $\begin{array}{l}\text { Change from } \\
\text { Pre to Post }\end{array}$ & 0.615 & 0.100 & 6.154 & 0.000 \\
\hline \multirow{4}{*}{$\begin{array}{l}\text { b. Above } \\
\text { Senior } \\
\text { Lecturer }\end{array}$} & Constant & 1.967 & 0.351 & 5.610 & 0.000 \\
\hline & Pre-1984 Trend & 0.116 & 0.041 & 2.815 & 0.008 \\
\hline & $\begin{array}{l}\text { Immediate } \\
\text { Change }\end{array}$ & -0.771 & 0.400 & -1.929 & 0.061 \\
\hline & $\begin{array}{l}\text { Change from } \\
\text { Pre to Post }\end{array}$ & 0.725 & 0.044 & 16.501 & 0.000 \\
\hline \multirow{4}{*}{$\begin{array}{ll}\text { c. } & \text { Senior } \\
\text { Lecturer }\end{array}$} & Constant & 5.684 & 0.220 & 25.863 & 0.000 \\
\hline & Pre-1984 Trend & 0.266 & 0.026 & 10.292 & 0.000 \\
\hline & $\begin{array}{l}\text { Immediate } \\
\text { Change }\end{array}$ & -1.520 & 0.250 & -6.069 & 0.000 \\
\hline & $\begin{array}{l}\text { Change from } \\
\text { Pre to Post }\end{array}$ & 0.989 & 0.028 & 35.922 & 0.000 \\
\hline \multirow[t]{4}{*}{ d. Lecturer } & Constant & 11.523 & 0.931 & 12.378 & 0.000 \\
\hline & Pre-1984 Trend & 0.649 & 0.109 & 5.933 & 0.000 \\
\hline & $\begin{array}{l}\text { Immediate } \\
\text { Change }\end{array}$ & 8.048 & 1.061 & 7.587 & 0.000 \\
\hline & $\begin{array}{l}\text { Change from } \\
\text { Pre to Post }\end{array}$ & 0.253 & 0.117 & 2.168 & 0.037 \\
\hline \multirow{4}{*}{$\begin{array}{ll}\text { e. } & \text { Below } \\
& \text { Lecturer }\end{array}$} & Constant & 31.625 & 0.715 & 44.206 & 0.000 \\
\hline & Pre-1984 Trend & 0.811 & 0.084 & 9.650 & 0.000 \\
\hline & $\begin{array}{l}\text { Immediate } \\
\text { Change }\end{array}$ & 3.893 & 0.815 & 4.775 & 0.000 \\
\hline & $\begin{array}{l}\text { Change from } \\
\text { Pre to Post }\end{array}$ & -0.469 & 0.090 & -5.230 & 0.000 \\
\hline
\end{tabular}

Women have accounted for over $50 \%$ of Below Lecturer positions since 1989 and for more than $40 \%$ of Lecturer positions since 1993 (they exceeded 50\% in 2008 for the first time). As numerical equity has been achieved, the rate of increase of female participation at the Below Lecturer and Lecturer levels has fallen, though the absolute number of women employed at these levels continues to increase.

\section{Japan}


There has been a marked increase in the slope of total female participation in academic positions in Japan since 1986 and the introduction of the EEOL. As seen in Table 4a, prior to 1986 , women were increasing their rate of total academic employment by $0.008 \%$ on average over the years 1970 to 1985 , although this increase was not statistically significant $(p$-value $>0.05)$. After 1986 , this rate has increased to $0.506 \%^{[8]}$ per year, a statistically significant change $(p$-value $<0.05)$. Thus, not only has the participation rate of academic women increased, but this rate is increasing much faster after 1986 than it was before the EEOL was introduced.

Table 4 Results of Breakpoint Analysis of Female Participation in Academic Staff; Japan

\begin{tabular}{|c|c|c|c|c|c|}
\hline Staff Level & & Coefficient & $\begin{array}{l}\text { Standard } \\
\text { Error }\end{array}$ & $t$-statistic & $p$-value \\
\hline \multirow{4}{*}{$\begin{array}{l}\text { a. } \\
\text { Total } \\
\text { Staff }\end{array}$} & Constant & 8.344 & 0.304 & 27.456 & 0.000 \\
\hline & Pre-1986 Trend & 0.008 & 0.031 & 0.248 & 0.806 \\
\hline & $\begin{array}{l}\text { Immediate } \\
\text { Change }\end{array}$ & -1.981 & 0.366 & -5.419 & 0.000 \\
\hline & $\begin{array}{l}\text { Change from } \\
\text { Pre to Post }\end{array}$ & 0.498 & 0.035 & 14.104 & 0.000 \\
\hline \multirow[t]{4}{*}{ b. Professor } & Constant & 2.440 & 0.206 & 11.859 & 0.000 \\
\hline & Pre-1986 Trend & 0.112 & 0.021 & 5.285 & 0.000 \\
\hline & $\begin{array}{l}\text { Immediate } \\
\text { Change }\end{array}$ & -1.094 & 0.247 & -4.421 & 0.000 \\
\hline & $\begin{array}{l}\text { Change from } \\
\text { Pre to Post }\end{array}$ & 0.232 & 0.024 & 9.726 & 0.000 \\
\hline \multirow{4}{*}{$\begin{array}{l}\text { c. Associate } \\
\text { Professor }\end{array}$} & Constant & 5.556 & 0.305 & 18.239 & 0.000 \\
\hline & Pre-1986 Trend & 0.092 & 0.032 & 2.919 & 0.006 \\
\hline & $\begin{array}{l}\text { Immediate } \\
\text { Change }\end{array}$ & -1.984 & 0.366 & -5.414 & 0.000 \\
\hline & $\begin{array}{l}\text { Change from } \\
\text { Pre to Post }\end{array}$ & 0.486 & 0.035 & 13.725 & 0.000 \\
\hline \multirow[t]{4}{*}{ d. Lecturer } & Constant & 10.815 & 0.445 & 24.270 & 0.000 \\
\hline & Pre-1986 Trend & -0.043 & 0.046 & -0.932 & 0.357 \\
\hline & $\begin{array}{l}\text { Immediate } \\
\text { Change }\end{array}$ & -2.695 & 0.536 & -5.027 & 0.000 \\
\hline & $\begin{array}{l}\text { Change from } \\
\text { Pre to Post }\end{array}$ & 0.851 & 0.052 & 16.431 & 0.000 \\
\hline \multirow[t]{4}{*}{ e. Assistant } & Constant & 14.883 & 0.404 & 36.849 & 0.000 \\
\hline & Pre-1986 Trend & -0.071 & 0.042 & -1.693 & 0.099 \\
\hline & $\begin{array}{l}\text { Immediate } \\
\text { Change }\end{array}$ & -2.922 & 0.486 & -6.014 & 0.000 \\
\hline & $\begin{array}{l}\text { Change from } \\
\text { Pre to Post }\end{array}$ & 0.740 & 0.047 & 15.778 & 0.000 \\
\hline
\end{tabular}


This pattern has occurred for all four levels of academic staff. In every case, not only has the overall female participation rate at each level increased, but the rate of change has accelerated in the years since 1986. For example, at the Professor level (Table 4b), the female participation rate has increased from an average of $0.112 \%$ per year prior to 1986 to $0.344 \%$ afterwards (both significant, as $p$-values $<0.05$ ). While the percentage of women at these levels was increasing prior to 1986, after 1986 the rate of increase has itself increased, indicating that the percentage of women filling these places is now increasing at a faster rate.

For Lecturers and Assistants the picture is somewhat different, as shown in Tables $4 \mathrm{~d}$ and 4e. Although both of these display clear rates of increase in the years following 1986 (Lecturers: 0.808\%; Assistants: 0.669\%), these academic levels both displayed decreasing levels of female staff in the years prior to 1986 (Lecturers: $-0.043 \%$; Assistants: $-0.071 \%$ ). These decreases were not statistically significant, as the $p$-value for both levels was greater than 0.05 .

\section{Discussion}

The continuing over-representation of women at the lower levels of academia in Japan and Australia can be seen as a measure of women's disadvantage, as female academics are often "concentrated in the periphery where they are denied access to an academic career" (Brown et al., 2010, p. 170).

One question raised by this research is why does the over-representation of women at the lower levels of academia continue? In the face of increasing female participation in higher education and significant legislative pressure, why are women still concentrated in the periphery of academia? I argue that this is due to the sociocultural construction of gender in both countries assigning the majority of the responsibility for family care to women, not men (Asmar, 1999; Kameda, 2011; Probert, 1998; White, 2004). Until this situation is resolved, 
and the sociocultural construction of both femininity and masculinity in Japan and Australia is revised to include an equal share in both work and non-work responsibilities for both men and women, there will be little change in overall gender inequalities in academic employment.

In this article I have shown that there has been improvement in the proportions of women in academic positions since the 1970s, but we are still a long way from parity. Commentators on the continued gender imbalance in universities argue that the organizational culture of universities, like most other workplaces, continues to require work to be prioritized over wider responsibilities. This disadvantages those with childcare responsibilities, who are more likely to be women. Moreover, the masculine model of education and employment is seen as gender neutral, which disadvantages women (and others) who do not confirm to the model of the independent, autonomous worker who is free from outside responsibilities. These aspects of disadvantage are not covered within AD/EO legislation, but are acknowledged within affirmative action legislation, policies or programs.

\section{Programs to Improve Women's Participation in University Employment Australia}

There have been numerous policies established within Australian universities which aim to increase female participation in academia, largely driven by Universities Australia (the former Australian Vice-Chancellors' Committee [AVCC]). The AVCC's first Action Plan for Women Employed in Australian Universities, 1999 to 2003 ("First Action Plan"), had three objectives: to promote the achievement of gender equity in Australian universities, to develop strategies for overcoming barriers to gender equity for university staff, and to refine AVCC and university staff development services to target gender equity more effectively (Australian ViceChancellors' Committee, 1999). 
As the First Action Plan came to an end, two significant studies on gender equity in Australia were published: Carrington and Pratt's (2003) study on gender disparities in the Australian higher education system and Winchester et al.'s (2005) report on promotion policies and practices in Australian universities. Both of these studies found that in the early 2000s universities employed slightly more women than men, though "most men in the university sector are employed as academics, while women are more likely to be employed as general staff" (Carrington and Pratt, 2003, p. 3). In order to encourage and support early career female academics, some universities implemented promotional policies which explicitly recognised teaching (an activity largely constructed as feminine) as well as research (Probert, 2005). These policies are largely thought to be fair "when considered from the point of view of women academic staff and gender equity" (Winchester et al., 2005, p. 2). Despite the presence of these policies in Australia for around 20 years, the number of women in senior academic positions remained limited. Both of these reports highlighted the gendered division of labour in the family and home as being the largest career disadvantage faced by women in academia (Carrington and Pratt, 2003; Winchester et al., 2005).

The First Action Plan was followed by the Second AVCC Action Plan for Women Employed in Australian Universities 2006-2010. This plan noted that "there have been demonstrable improvements from 1999 to 2005 at most classification levels, and significant ones at Level C academic staff', though progress had been uneven across the sector (Australian Vice-Chancellors' Committee, 2006, p. 1). The Second Action Plan set specific targets for all Australian universities, including an increase of women at Level E from $16 \%$ in 2004 to $25 \%$ by 2010 , and from $24 \%$ at Level D in 2004 to $35 \%$ by $2010^{\text {[9] }}$ (Australian Vice-Chancellors' Committee, 2006). This Second Action Plan was succeeded by the Universities Australia Strategy for Women: 2011-2014. The Strategy notes that "there is evidence that the career paths of academic men and women are different, with those of men 
being quite linear and those of women often being more labyrinthine...these different patterns need to be taken into account as new members of staff are recruited" (Universities Australia, 2010, p. 2). Little acknowledgement is made in the Strategy document of the overrepresentation of women at the lower academic levels or women's over-representation in terms of casual teaching staff. Recent press reports suggest that there has been a decline in the number of women in senior research positions since 2010 (Lane, 2012, p. 29).

Japan

The 1986 Equal Employment Opportunity Law does not stand alone in trying to increase workplace equality in Japan. A series of government policies and programs have aimed to increase female participation in areas where women workers have historically been a minority. For example, the Headquarters for the Promotion of Gender Equality launched the National Plan of Action for Promotion of a Gender-Equal Society by the Year 2000 in 1996, as part of Japan's response to the Beijing Action Plan which resulted from the Fourth World Conference on Women held in Beijing in 1995 and in conjunction with the Danjo Kyōdo Sankaku Shakai Kihon-hō (Basic Law for a Gender Equal Society) introduced in 1999. The National Plan of Action does not include specific targets for the participation of women in academic positions.

Positive action has been implemented in many research-focused areas in Japan in order to improve the employment opportunities of women and men in Japan. Following the National Plan, in 2000, the Association of National Universities in Japan presented a report regarding the promotion of gender equality at National Universities which included the specific aim to "raise the ratio of female staff to $20 \%$ by 2010" (Association of National Universities, 2010, p. 3). This goal has been achieved for total academic staff across Japan's 
National, Public and Private universities ${ }^{[10]}$ (Table 1 above), but not by the National Universities alone (Association of National Universities, 2010).

An important step in encouraging female participation in academia is encouraging the research activities of women at universities. Through the Ministry of Education, Culture, Sports, Science and Technology (MEXT), the Government of Japan has established several on-going programs to provide support for female researchers in Japan (Cabinet Office of Japan, 2011). These include the Josei kenkyūsha shien moderu ikusei jigyō (Program Supporting Activities for Female Researchers) and the Josei kenkyūsha yōsei kaikaku kasoku jigyō (Program Supporting Positive Action for Female Researchers).

The Program Supporting Activities for Female Researchers began in 2006 and funds support projects for female researchers at 55 universities and research institutions, such as the establishment or expansion of child care facilities and offices for supporting female researchers (Miura, 2012). The Program Supporting Positive Action for Female Researchers was launched in 2009, and outlines a five-year plan whereby 12 universities ${ }^{[11]}$ are given financial support to hire new female academic staff. Under this program, "over 300 female researchers will get new positions in those universities" by 2015 (Miura, 2012, p. 1).

Programs and policies such as these indicate an acknowledgement by universities themselves of the importance of gender equity amongst academic staff (Winchester et al., 2005). Through these programs, universities in Japan and Australia signal that it is important to include a greater number of female academic staff, and that in order to do so, aspects of culture within the university must change.

\section{Conclusion}

Both Australia and Japan have seen increases across the board in female participation rates in academic employment since the mid-1980s. There has also been an improvement in the rate of increase of gender equity.However, the social construction of gender in both 
countries continues to attribute the majority of family responsibilities on women, thus limiting their career options. In the Japanese case, since the Equal Employment Opportunity Act was introduced in 1986, the rate of increase of female participation has increased for all levels of academic staff. A similar change has occurred in Australian universities since the 1984 Sex Discrimination Act was introduced, at least in terms of total academic staff, Above Senior Lecturers, and Senior Lecturers. While the rate of increase of female participation at the Lecturer and Below Lecturer levels has slowed in recent years, the number of women employed at these levels continues to increase. Whether this slowdown is a side effect of the increased casualization of Australia's academic workforce is a potential issue for future research. The effect of increased casualization on the gender balance of academic positions in Japan should also be examined.

Though gender imbalances persist in academic employment in Australia and Japan, this inequality is being reduced, partially due to the acknowledgment of a wider range of causes of disadvantage as highlighted within affirmative action policies. Although no causation can be identified at this stage between the introduction of $\mathrm{AD} / \mathrm{EO}$ legislation and increased female participation, there is clear correlation. While issues such as differences in work and family burdens for male and female academic staff remain, I have shown how female participation in academic teaching has improved between 1970 and 2010, with rates of female participation increasing in the years following the introduction of anti-sex discrimination legislation and affirmative action policies. 


\section{References}

Acker, J. (1990), "Hierarchies, Jobs, Bodies: A Theory of Gendered Organizations", Gender \& Society, Vol. 4, No. 2, pp. 139-158.

Acker, J. (2012), "Gendered Organizations and Intersectionality: Problems and Possibilities", Equality, Diversity and Inclusion: An International Journal, Vol. 31, No. 3, pp. 214224.

Anker, R. (1997). "Theories of Occupational Segregation by Sex: An Overview", International Labour Review, Vol. 136, No. 3, pp. 311-335.

(1998). Gender and Jobs: Sex Segregation of Occupations in the World, International Labour Office, Geneva.

Asmar, C. (1999), "Is there a Gendered Agenda in Academia? The Research Experience of Female and Male PhD Graduates in Australian Universities", Higher Education, Vol. 38, No., pp. 255-273.

Association of National Universities (2010), Kokuritsu Daigaku ni okeru Danjo Kyōdō Sankaku Suishin no Jisshi ni Kansuru, Association of National Universities, Tokyo.

Australian Bureau of Statistics (1971), Official Year Book of Australia 1971, Australian Bureau of Statistics, Canberra.

Australian Bureau of Statistics (1984), Official Year Book of Australia 1984, Australian Bureau of Statistics, Canberra.

Australian Vice-Chancellors' Committee (1999), Action Plan for Women Employed in Australian Universities, 1999 to 2003, Australian Vice-Chancellors' Committee, Canberra.

Australian Vice-Chancellors' Committee (2006), The Second AVCC Action Plan for Women Employed in Australian Universities - 2006-2010, Australian Vice-Chancellors' Committee, Canberra.

Bacchi, C.L. (1990). Same Difference: Feminism ad Sexual Difference,Allen\& Unwin, Sydney.

Bailyn, L. (2003). "Academic Careers and Gender Equity: Lessons Learned from MIT”, Gender, Work and Organization, Vol. 10, No. 2, pp. 137-153.

Bain, O. and Cummings, W. (2000), "Academe's Glass Ceiling: Societal, Professional/Organizational, and Institutional Barriers to the Career Advancement of Academic Women", Comparative Education Review, Vol. 44, No. 4, pp. 493-514.

Baird, M. (2011). "Women and Work in Australia: A Theoretical and Historical Overview", in Murray, P.A., Kramar R. and McGraw, P. (Eds.), Women at Work: Research, Policy and Practice, Tilde University Press, Prahran, Vic.

Bleijenbergh, I.L., van Engen, M.L. and Vinkenburg, C.J. (2013), "Othering Women: Fluid Images of the Ideal Academic", Equality, Diversity and Inclusion: An International Journal, Vol. 32, No. 1, pp. 22-35.

Bradley, K. \& Charles, M. (2003), “Uneven Inroads: Understanding Women's Status in Higher Education", Research in Sociology of Education, Vol. 14, pp. 247-274.

Brown, T., Goodman, J. \& Yasukawa, K. (2010), "Academic Casualization in Australia: Class Divisions in the University", Journal of Industrial Relations, Vol. 52, No. 2, pp. 169-182.

Butler, J. (1997). "Further Reflections of Conversations of our Time", Diacritics, Vol. 27, No. 1, pp. 13-15.

Cabinet Office of Japan (2011), "Promotion of 'Positive Action' - Aiming to attain the target of '30\% by 2020'”, White Paper on Gender Equality 2011: Summary, available at: http://www.gender.go.jp/english_contents/category/pub/whitepaper/pdf/ewp2011.pdf (accessed May 28 2012). 
Carothers, B.J. \& Reis, H.T. (2012). "Men and Women Are From Earth: Examining the Latent Structure of Gender", Journal of Personality and Social Psychology, Vol. 104, No. 2, pp. 385-407.

Carrington, K. \& Pratt, A. (2003), How Far Have We Come? Gender Disparities in the Australian Higher Education System, Information and Research Services, Dept. of the Parliamentary Library, Canberra.

Cejka, M.A. \& Eagly, A.H. (1999). "Gender-Stereotypic Images of Occupations Correspond to the Sex Segregation of Employment", Personality and Social Psychology Bulletin, Vol. 25, No. 4, pp. 413-423.

Department of Education, Employment and Workplace Relations. (2011), Students: Selected Higher Education Statistics 2010, Department of Education, Employment and Workplace Relations, Canberra.

Flowers, P.R. (2009), Refugees, Women and Weapons: International Norm Adoption and Compliance in Japan, Stanford University Press, Stanford.

Frank, D.J. \& Meyer, J.W. (2007), "University Expansion and the Knowledge Society", Theory and Society, Vol. 36, No. 4, pp. 287-311.

Gaze, B. (2010), "The Sex Discrimination Act at 25: Reflections on the Past, Present and Future", Thornton, M., Sex Discrimination in Uncertain Times, The Australian National University Press, Canberra, pp. 107-132.

Heilman, M.E. \& Wallen, A.S. (2010). "Wimpy and Undeserving of Respect: Penalties for Men's Gender-Inconsistent Success", Journal of Experimental Social Psychology, Vol. 46, No. 4, pp. 664-667.

Kameda, A. (2011), "The Advancement of Women in Science and Technology", in FujimuraFanselow, K. (Ed.) Transforming Japan: How Feminism and Diversity are Making a Difference, The Feminist Press, New York.

Kim, T. (2005). "Internationalisation of Higher Education in South Korea: Reality, Rhetoric, and Disparity in Academic Culture and Identities", Australian Journal of Education, Vol. 49, No. 1, pp. 89-103.

Lake, M. (1999), Getting Equal: The History of Australian Feminism, Allen and Unwin, Sydney.

Lane, B. (2012), "Women falling foul of research focus", The Australian, 12 December, p. 29.

Luke, C. (2001), Globalization and Women in Academia: North/West-South/East, L. Erlbaum Associates, Mahwah, NJ.

Mackie, V. (2003), Feminism in Modern Japan, Cambridge University Press, Cambridge.

Miura, Y. "The Positive Action in Japan", International Workshop on "Women and Science/Technology" in East Asia, January 30, 2012, Ochanomizu University, Japan.

Monbushō (2011), Monbu Kagaku Tōkei Yōran 2010, Monbusho $\square$ Daijin Kanbo $\square$ Cho $\square$ sa To $\square$ kei Kikakuka, Tokyo.

Oda, H. (1992), Japanese Law, Butterworths, London.

Okimoto, T.G. \& Brescoll, V.L. (2010). "The Price of Power: Power Seeking and Backlash Against Female Politicians", Personality and Social Psychology Bulletin, Vol. 36, No. 7, pp. 923-936.

Panteli, N. Stack, J. \& Ramsey, H. (2001). "Gendered Patterns in Computing Work in the Late 1990s", New Technology, Work and Employment, Vol. 16, No. 1, pp. 3-17.

Perrin, N.A. (2009), Analysis of Interrupted Time Series with Segmented Regression, The Oregon Program Evaluators Network Annual Conference, Portland, Oregon.

Poole, G.S. (2010), The Japanese Professor: An Ethnography of a University Faculty, Sense, Rotterdam; Boston. 
Probert, B. (1998), "Working in Australian Universities: Pay Equality for Men and Women?", Australian Univerisites Review, Vol. 41, No. 2, pp. 33-42.

(2005), "'I Just Couldn't Fit In': Gender and Unequal Outcomes in Academic

Careers", Gender, Work and Organization, Vol. 12, No. 1, pp. 50-72.

Probert, B., Ewer, P. \& Whiting K. (1998). Gender Pay Equity in Australian Higher Education, The National Tertiary Education Union, Melbourne.

Sawer, M. (2004), The Commonwealth Sex Discrimination Act: Aspirations and Apprehensions, Forum to mark the 20th Anniversary of the Sex Discrimination Act, The Darlington Centre, University of Sydney, Australia.

Scott, J.W. (1988). Gender and the Politics of History. Rev. ed. Columbia University Press, New York.

Skilbeck, M, \& Esnault, E. (1993), Higher Education: An Overview of Issues in OECD Countries", The Transition from Elite to Mass Higher Education, Sydney, Australia.

Sōmushō Tōkeikyoku Tōkei Kenshūjo (1971), Nihon Tōkei Nenkan (Japan Statistical Yearbook) 1971, Nihon Tōkei Kyōkai, Tokyo.

Sōmushō Tōkeikyoku Tōkei Kenshūjo (1987), Nihon Tōkei Nenkan (Japan Statistical Yearbook) 1987, Nihon Tōkei Kyōkai, Tokyo.

Sōmushō Tōkeikyoku Tōkei Kenshūjo (2011), Nihon Tōkei Nenkan (Japan Statistical Yearbook) 2011, Tokyo: Nihon Tōkei Kyōkai.

Strachan, G., Burgess, J. \& Henderson, L. (2007), "Equal Employment Opportunity Legislation and Policies: The Australian Experience", Equal Opportunities International, Vol. 26, No. 5, pp. 525-540.

Thornton, M. (1990). The Liberal Promise: Anti-discrimination Legislation in Australia, Oxford University Press, Melbourne.

Thornton M. \& Luker, T. (2010), “The Sex Discrimination Act and its Rocky Rite of Passage", in Thornton, M. (Ed), Sex Discrimination in Uncertain Times, ANU EPress, Canberra.

Tyler, J.M. \& McCullough, J.D (2009). "Violating Prescriptive Stereotypes on Job Resumes: A Self-Presentational Perspective", Management Communication Quarterly, Vol. 23. No. 2, 272-287.

Universities Australia (2010), Strategy for Women: 2011-2014, Universities Australia, Canberra.

Upham, F.K. (1987), Law and Social Change in Postwar Japan, Harvard University Press, Cambridge, Massachusetts.

Verbos, A.K. \& Humphries, M.T. (2012), "Decoupling equality, diversity, and inclusion from liberal projects: Hailing indigenous contributions to institutional change", Equality, Diversity and Inclusion: An International Journal, Vol. 31, No. 5, pp. 506-525.

Wagner, A.K., Soumerai, S.B., Zhang, F. \& Ross-Degnan, D. (2002), "Segmented Regression Analysis of Interrupted Time Series Studies in Medication Use Research", Journal of Clinical Pharmacy and Therapeutics, Vol. 27, No., pp. 229-309.

Webb, J. (1997), "The Politics of Equal Opportunity”, Gender, Work \& Organization, Vol. 4, No. 3, pp. 159-169.

White, K. (2004), “The Leaking Pipeline: Women Postgraduate and Early Career Researchers in Australia", Tertiary Education and Management, Vol. 10, pp. 227-241.

Winchester, H., Chesterman, C., Lorenzo, S. \& Browning, L. (2005), The Great Barrier Myth: An Investigation of Promotion Policy and Practice in Australian Universities, Australian Vice-Chancellors' Committee, Canberra.

Wirth, L. (2001), Breaking through the Glass Ceiling: Women in Management, International Labour Office, Geneva. 


\footnotetext{
${ }^{1}$ The 2007 Monbu Tōkei Yōran saw two changes in the job categories of some university staff in Japan. What were Assistant Professors (jokyōju) were now Associate Professors (junkyojju); Tutors (joshu) were now split into Assistant Teachers (jokyō) and Tutors (joshu). For my analysis, I have combined Assistant Teachers and Tutors into one category, for which I use the term Assistant.

${ }^{2}$ Source: Sōmushō Tōkeikyoku Tōkei Kenshūjo (1971, 2011).

${ }^{3}$ Source: Sōmushō Tōkeikyoku Tōkei Kenshūjo (1971, 1987, 2011).

${ }^{4}$ In both the Australian and Japanese cases, these numbers report full-time staff only. The educational systems of both countries have seen a significant rise in the number of sessional, part-time, casual or hijōkin (nonregular) teaching staff over the past few years. If casual staff were included, the numbers of staff, particularly at the lowest level (Tutors/Below Lecturers), would be much higher. For a discussion on the implications of the increasing number of casual academic teaching staff in the Australian context, see Brown et al., 2010.

${ }^{5}$ Source: Australian Bureau of Statistics $(1971,1984)$, Department of Education, Employment and Workplace Relations (2011).

${ }^{6}$ Source: Australian Bureau of Statistics (1971), Department of Education, Employment and Workplace Relations (2011).

${ }^{7}$ An example of this is the past practice of having different retirement ages for male and female employees, and in many cases, female employees would retire even earlier - upon marriage, childbirth, or reaching the age of thirty. This had been challenged through several lawsuits - most notably, Suzuki vs. Sumitomo Cement - as being unconstitutional, and was slowly decreasing in practice prior to the introduction of the EEOL. See, for example, Upham, 1987.

${ }^{8}$ The sum of "Pre-1986 Trend" and "Change from Pre to Post" is the post-1986 slope (the sum of $\beta_{1}$ and $\beta_{3}$ ).

${ }^{9}$ Level D and Level E are combined to form the "Above Senior Lecturer" level in the Department of Education's statistics. In 2010, 26.67\% of Above Senior Lecturers in Australia were female.

${ }^{10}$ Public universities differ from National ones in that they operate under prefectural (or other local) government rather than the national government, while private universities gain substantially less government funding.

${ }^{11}$ The twelve universities are: Hokkaido University, Tohoku University, Chiba University, Tokyo Agriculture and Technology University, Nagoya University, Kyoto University, Kobe University, Nara Women's University, Hiroshima University, Kyushu University and Kumamoto University (Miura, 2012).
} 